\title{
The American version of the Welfare State
}

\author{
Edward D. Berkowitz
}

To explain the origins and development of the American welfare state in a single, succinct article lies well beyond the boundaries of possibility. ${ }^{1}$ This essay attempts something much more modest. Instead of a comprehensive account of America's social policy, the essay identifies three distinctive features of the American welfare state. Federalism, judicial review, and welfare capitalism account for many of the differences between the American and the European versions of the welfare state.

\section{Federalism and the American Welfare State}

Federalism refers to the division of power between the state and national governments. Each of the fifty states enjoys substantial power to make its own form of social policy. To comprehend American social policy, therefore, often requires the analyst to review the policies of each of the fifty states. The historian finds substantial evidence of the workings of federalism throughout the development of the American welfare state.

In the late nineteenth century, a large system of pensions, based on service during the Civil War, developed. These began as payments to soldiers who had been injured or killed in the Civil War and gradually became fullscale social welfare benefits, including old-age pensions for the soldiers of the Civil War and their families. The very existence of these pensions showed that, even in the nineteenth century, the national government was not averse to the existence of large-scale social benefits. At the same time, federalism played an important role in the civil war pension program. Most people in the southern states that had seceded from the union failed to qualify. They depended on the far less certain generosity of state and local governments. ${ }^{2}$

During the progressive era between 1900 and 1920, Americans initiated an extensive workers' compensation program for employees injured in the job. This program permitted injured workmen to receive a cash payment and free medical care during the period of convalescence after an industrial accident. As in all large-scale American programs, the scope of the program was impressive. Still, the program operated at the state, not the national, level. Each state passed its own version of a workers' compensation. Although the states tended to emulate one another, substantial state-by-state variations existed in the amount paid to injured workers. Furthermore, in the approximately eighty years since the passage of workers' compensation laws, these laws have never been nationalized. States continue to take the lead in this area of policy. ${ }^{3}$

Two years after Franklin Roosevelt became President, America passed its major social welfare law. The Social Security Act of 1935 was comprehensive, covering the risks of old age, unemployment, ill health, and disability, and it was extensive, including such features as special programs to 
protect the health of infants and crippled children and to rehabilitate people with disabilities. Indeed, as the sociologist Edwin Amenta shows in a forthcoming book, America was a world leader in social welfare spending during the 1930s. ${ }^{4}$

At the same time, the Social Security Act respected the American tradition of federalism. Nearly all of the programs authorized by the Social Security Act, with the significant exception of old-age insurance, operated at the state level. Hence, an employed worker in Chicago went to an employment security office run by the state of Illinois if he or she expected to receive unemployment compensation. This worker from Illinois would, in all probability, receive more liberal compensation than would a similar worker in Mississippi. Wide variations existed from state to state in nearly all forms of social provision sanctioned by the Social Security Act. Benefits paid to single parents with dependent children were, for example, much higher in New York than they were in Alabama. The program that provided vocational guidance and other services to people with disabilities, known as vocational rehabilitation, functioned completely differently in Massachusetts than it did in Nevada.

Almost alone among American social programs, old-age insurance, another of the programs authorized by the 1935 Social Security Act, is administered by the federal government (the national government in Washington, D.C.). This program has grown into America's largest and most successful social program, as indicated by the fact that, in terms of the generosity of old-age assistance, the United States ranks near the top of all the major industrialized countries. ${ }^{5}$ Yet even as old-age insurance, which Americans somewhat confusingly refer to as Social Security, has expanded, legislators have respected the traditions of American federalism.

In 1956, to cite an example, Congress permitted the Social Security program to begin a program of disability pensions for workers with severe physical or mental impairments. Instead of entrusting the task of examining people for disability benefits to the federal government, Congress asked each of the states to start a disability determination office. As a result, states have different rates of admission to the disability insurance program. In some states, a comparatively large percentage of the applicants are accepted. In other states, relatively few disability applicants receive benefits. ${ }^{6}$

In 1965, Congress authorized what Americans refer to as the Medicare program. This program enabled Social Security beneficiaries over 65 to have many of their medical and hospital bills paid by the federal government. Instead of allowing the federal government to administer this large health insurance program, Congress decided to permit private organizations, which differ from state to state and region to region, to handle all of the financial arrangements for Medicare. ${ }^{7}$

In the same year that President Lyndon Johnson managed to secure the enactment of Medicare, he also succeeded in convincing the legislature to pass Medicaid. Medicaid was health insurance for poor people unable to pay their medical bills. Welfare recipients, such as families with dependent children, 
were the primary beneficiaries. Medicaid differed from Medicare in that its recipients had to pass a means test - prove that they were poor, in other words - before they could receive benefits. In running this program, Congress once again entrusted major responsibilities to the states. The national government in Washington supplied the states with money (although it also expected states to contribute money on their own) and made certain requirements of them, such as ordering them to cover families with dependent children and pregnant women. Despite the financial assistance and the requirements, Medicaid remained very much a state entity, with very wide variations in the program from state to state. The fact that the state of Arizona never even passed a Medicaid program and made other arrangements for the medically indigent illustrated the extent of the diversity.

As this quick historical overview of events from the late nineteenth century to the Great Society of Lyndon Johnson indicates, states have remained an important force in American social welfare politics. Although it is fashionable to think of the growth of the federal government in this century, states now have more influence over social policy than at any time since the early 1930s. The current Republican Congress has made returning power to the states one of its primary goals. Accordingly, House Speaker Newt Gingrich has endorsed the concept of turning welfare and Medicaid over to the states, with little direction from the central government.

Federalism, therefore, continues to be a key to understanding the American welfare state. A proper comparison between the social benefits of a foreign country and the United States of America should focus on a single state, not on the central government. The large size of the United States encourages this sort of comparison. If one were looking to compare New Zealand and the United States, for example, the appropriate scale of comparison might be between that country and the state of Kansas.

\section{The Courts and the American Welfare State}

The courts constitute a second force of great importance in the development of the American welfare state. Perhaps in reaction to the country's democratic potential, the courts have always exercised the right to review the actions of the state legislatures and of Congress. This right of judicial review, which the courts claimed very early in the history of the American republic, allows the courts to decide if a particular law conforms to the terms of the Constitution. By exercising the right of judicial review, the court has the power to invalidate the actions of the state or federal legislature.

Throughout the course of American history, the courts have taken it upon themselves to declare laws unconstitutional or to limit the scope of a particular law. In 1895, for example, the Supreme Court, which is the ultimate court of review, ruled that the 1890 Sherman Act, which made it illegal for businesses to restrict competition by forming a trust or a monopoly, did not apply to the manufacture of sugar and by extension to any form of manufacturing. The reason was somewhat tortured, involving limitations on 


\section{Edward D. Berkowitz}

the power of Congress. As one authority explained, 'the Court found that an apparent monopoly of sugar refining was beyond the reach of the Sherman Act because manufacturing, even if for sale in interstate commerce, was not itself commerce and hence was not subject to congressional restraint'. ${ }^{8}$ In so interpreting the actions of Congress, the Supreme Court made it very difficult for the federal government to use its power to break up monopolies. The famous 1896 decision in the case of Plessy v. Ferguson permitted the existence of 'separate but equal' facilities for blacks and whites on street cars and other forms of public accommodation, even though the fourteenth amendment of the constitution forbade state governments to 'deny to any person within its jurisdiction the equal protection of the law'.

The existence of judicial review meant, in effect, that legislators always acted with the courts looking over their shoulder. The legislatures only passed laws that they felt could withstand the scrutiny of the courts, and even then the laws sometimes failed to pass judicial muster. In September 1918 the District of Columbia, the home of the federal government which functioned somewhat like a state, passed a minimum wage law for women. The strategy of restricting the law to women, rather than to both men and women, reflected the sense that the Court would permit local government more latitude in regulating the working conditions of women than of men. Women, it was argued, required special protection from workplace hazards. In 1923, the Supreme Court failed to go along with this reasoning and used its powers to overturn the District of Columbia law. The Court ruled that the law interfered with the right of women to enter freely into a labor contract.

In the nineteen thirties, a major battle developed between Franklin Roosevelt's administration and the Supreme Court. At issue were the laws passed in 1933 as part of what historians refer to as the first New Deal. At the heart of the first New Deal stood a law to regulate industrial conditions and another law to regulate agricultural conditions. In 1935, the Supreme Court invalidated the law concerning industrial conditions, and the next year the Court overturned the law governing agricultural conditions. In retaliation, President Roosevelt threatened to pack the Supreme Court with justices sympathetic to his programs. In the face of that threat, the Supreme Court altered some of its positions and upheld the key laws of 1935, including the all-important Social Security Act. ${ }^{9}$

The structure of the Social Security Act owed a great deal to the deference of the executive branch of government to the judicial. The key programs of the Act relied upon the taxing power of the federal government, in part because Secretary of Labor Frances Perkins had received informal assurances from one of the Supreme Court justices that, as one authority, put it, 'the taxing power of the federal government was sweeping indeed'. Looking back at the creation of the Social Security Act, Arthur Altmeyer, who served as chairman of the Social Security Board from 1937 to 1953, remarked, 'in 1934 the previous decisions of the United States Supreme Court had created considerable doubt as to how far the Constitution of the United States permitted the federal government to go in enacting social legislation'. ${ }^{10}$ 
When these doubts were finally overcome and the Supreme Court upheld the key provisions of the Social Security Act in 1937, the supporters and administrators of the Act felt a tremendous sense of relief. Wilbur Cohen, an important employee of the Social Security and later America's chief minister for Health, Education, and Welfare, described the 1937 decision as a 'momentous experience'. ${ }^{11}$

Even after 1937, the courts continued to exert tremendous influence over American social policy. This influence was as often in a liberal as in a conservative direction. In the early 1970s, the federal courts decided many influential cases that applied rights-based criteria to activities in which the federal government provided federal financial assistance. In the Mills case, for example, a federal district court ruled that the equal-protection clause required the provision of a free, appropriate, public education for all handicapped children, just as such an education was provided to nonhandicapped children. Lack of funds could not be used as an excuse. Instead, the District of Columbia school system, the defendant in the case, must spend its available funds so that 'no child is entirely excluded from a publicly supported education consistent with his needs and ability'. ${ }^{12}$ In the 1971 Wyatt case, public-interest lawyers, working with an organization known as the Mental Health Law Project, successfully challenged the state of Alabama's commitment procedures and conditions of confinement for people in mental institutions. This case led to direct efforts to achieve the removal of people from mental retardation facilities, such as Willowbrook on Staten Island, through legal-consent decrees. ${ }^{13}$

If the court could influence the population of facilities for the mentally retarded and the mentally ill, it also had tremendous influence over the number of people on the nation's disability rolls. In this regard, the courts interpreted just how strict policymakers should be in determining whether someone was disabled and hence entitled to a pension. Did, for example, Congress intend for someone with a disability to sell pencils on the street corner or did it intend for the law's stringent provisions to be interpreted in a more liberal manner? In 1990 the Supreme Court decided the case of Sullivan $v$. Zebley. The Court ruled that, in awarding welfare benefits based on disability to children, the responsible federal agency needed to consider 'functional limitations'. That meant that the federal agency had to reexamine the cases of some 450,000 children who had previously been denied benefits. It also helped to lead to a tremendous expansion of the disability rolls in the late nineteen eighties and early nineteen nineties, even without the benefit of a formal change in the disability insurance law. ${ }^{14}$

The courts, then, have exercised considerable power over every stage of the development of the American welfare state. In analyzing American social policy, one must consider the courts to be as important as either the executive or legislative branches of government. The veto power of the court through judicial review deserves primary consideration but so too do the powers of the court to alter the scope of existing legislation. Nor, as these examples have revealed, does the court serve only to restrict the size and 


\section{Edward D. Berkowitz}

scope of the American welfare state; it also has served as a powerful force in the expansion of such programs as Aid to Families with Dependent Children and Social Security Disability Insurance. In general, the restrictive power of the court peaked around 1935; the expansive power of the courts remains a factor in modern social policy.

\section{Welfare Capitalism}

The public power of the courts might be contrasted with the private power of corporations. From the beginning of this century to the present day, corporations have played an important role in America's welfare state. Almost alone among the major industrial powers, the United States depends upon private companies both to finance and even to important social benefits to company employees. The typical American, for example, continues to receive health insurance through his employer, not through the state.

In large measure, the reliance on corporations goes back to the welfare capitalism movement at the turn of the century. Early in this century, corporations that operated in national markets and maintained business operations in scattered locations discovered how ineffective it was to deal with local authorities in matters of social welfare policy. If nothing else, the rules often differed from place to place. At the same time, these corporations faced the problem of maintaining a productive and healthy workplace and sought means of reducing turnover among their employees. With this motivation, the corporations developed practices that married the provision of social welfare services with normal business operations. The result was a series of innovations that became known as welfare capitalism.

A good example of welfare capitalism in operation was the campaign to promote safety in the work place. The safety movement stemmed from the more general progressive reform agitation at the turn of the century. In common with other progressive coalitions, the safety movement consisted of a series of interlocking government agencies, such as the Bureau of Labor Statistics, and private organizations, such as the National Safety Council. The focus tended to be on state, rather than the federal government, and on companies, rather than on an industry or the economy. Stated in the simplest terms, the movement tried to interest employers in making an investment in safety.

The activities of the United States Steel Corporation illustrated how safety campaigns operated within individual companies. From the moment of its creation in 1901, US Steel became the largest and potentially the most hazardous corporation in the world. Steel making already had a reputation as a highly dangerous occupation, and US Steel also owned coal mines, which were notoriously treacherous places in which to work. The corporation began its active involvement in the safety movement in May 1906. Judge Elbert Gary, the chairman, told the managers of the subsidiary companies that the Board of Directors would appropriate money for accident reduction. In April 1908 , the company created a central committee on safety that served as a 
clearinghouse for safety information among the 143 manufacturing plants. This committee eventually formulated recommendations for safe production procedures that, according to company officials, produced beneficial results. Between 1910 and 1927, for example, the accident frequency in the steel industry dropped nearly 74 percent. US Steel boasted in the 1920 s that its safety program saved a million dollars a year. ${ }^{15}$

By the end of the postwar decade, over ninety percent of companies surveyed in one national study operated safety programs; seventy percent operated group insurance plans; and sixty percent had mutual aid associations. In the fifteen years after 1910 more than 181 companies established retirement pension programs to minister to the needs of workers with continuous employment records within individual firms. Benefits depended upon good employee behavior. If the worker struck, joined an American Federation of Labor union (as opposed to an acceptable union sponsored by the company itself), changed jobs, or appeared to hold radical political beliefs, he or she could lose these benefits, low as they often were. Despite these elements of old-fashioned social control, however, a precedent was being established that systematic retirement benefits of some sort were due to faithful employees. This development occurred at a time when state retirement plans were few and fragmentary, and federal programs were nonexistent. ${ }^{16}$

Although welfare capitalism never reached a majority of the American workers, it nonetheless played an important role in the formation of the American welfare state. In state programs such as workers' compensation, large employers in many states won the right to 'contract out'. That meant that they did not need to purchase insurance against the risk of paying for industrial accidents from a state fund or a private insurance company. Instead, the company could self-insure, meaning that it would meet the problem of industrial accidents by itself. In the 1930s, Congress very nearly permitted large employers to contract out of old-age insurance in the Social Security Act. That would have meant that employees in America's largest corporations would not have participated in Social Security. Instead, they would have continued to receive their pension and other benefits exclusively from the company.

To be sure, private industry reached an accommodation with the Social Security program after 1950. Nonetheless, the prevailing idea in America was that pensions were to be provided through a tripartite arrangement. By the terms of this arrangement, a retired worker depended upon his private savings, his company pension, and his Social Security check for his financial survival.

During the 1940s, health care became an important fringe benefit that companies provided for their employees. The development of this private market for health insurance made it difficult for Congress to pass a national health insurance program in the manner of the British Beveridge plan. This failure occurred despite the deep interest of President Truman in national health insurance during the period between 1945 and 1950. The best the government could do was to finance health care for retirees and for the medically indigent, and that only happened after a protracted political debate. 


\section{Edward D. Berkowitz}

National health insurance remains a lively subject in America. Recently, President Bill Clinton attempted to interest Congress in a comprehensive national health insurance program. The President recognized that the American system was breaking down. Many people were employed, yet they lacked health insurance. As a result, they faced the possibility of going into the hospital without any sure means of paying the bills. Hospitals responded by loading the costs of what the industry called 'uncompensated care' on those with health insurance. As a result, the costs of health insurance soared, forcing employers to ask their employees to bear a greater proportion of the cost. Even with the system unravelling, President Clinton turned to the strategy of mandating. He wanted to require private employers to provide health insurance for their employees and offered to assist them in purchasing relatively inexpensive medical care. In other words, even this relatively liberal President wanted to preserve the system under which employers, not the national government, financed health care.

Many large employers do not even purchase health insurance from private companies. Instead, they self-insure and manage their own health care. Companies find that they are better able to monitor health care claims and control unnecessary expenditures if they scrutinize these claims themselves, rather than entrusting this task to an insurance company. Managed care also takes the form of encouraging employees to join health maintenance organizations which try to hold down health care costs by reducing the number of referrals to specialists and limiting the number and length of hospital stays.

Few Americans would claim that they have solved the problems of guaranteeing access to quality health care and controlling health care costs. Most would concede, however, that whatever solution gets adopted will depend heavily on the actions of private companies rather than on the coercive power of the national government. Indeed, many analysts feel that the state governments have moved ahead of the federal government in this area, reinforcing the trend of augmenting the responsibilities of state governments. Private companies and the welfare capitalist tradition remain important influences over American social welfare practice.

\section{Conclusion}

I would contend that any discussion of the unique nature of the American welfare state must consider the trinity of forces I have outlined here. States, courts, and private companies all occupy a privileged position in the American polity. Understanding the American welfare state requires coming to grips with the interplay between these forces and the political particulars of a historical moment. The progressive era, the New Deal, and the Great Society were all periods in which political circumstances made the passage of legislation possible. The result was the initiation of workers' compensation in the progressive era, the passage of the Social Security Act in 1935, and the start of Medicare and Medicaid in 1965. Even in these eras of state activism, however, policymakers contended with the influence of states, courts, and 
private companies. Hence, states retained considerable influence in the workers' compensation laws and in many of the programs of the Social Security Act. Courts continued both to expand and contract existing programs, and private companies preserved their historical role as providers of social welfare services. Whatever should happen in the future, states, courts, and private companies will continue to define the American approach to the welfare state.

Notes:

1. I have tried to explain the development of the American welfare state in such publications as America's Welfare State from Roosevelt to Reagan (Baltimore 1991).

2. Theda Skocpol, Social policy in the United States: Future possibilities in historical perspective (Princeton, New Jersey 1995) 37-71.

3. Walter Dodd, Administration of workmen's compensation (New York 1936).

4. Professor Amenta was kind enough to share an early version of his manuscript with me.

5. Theodore R. Marmor, Jerry L. Mashaw, and Phillip L. Harvey, America's misunderstood welfare state: persistent myths, enduring realities (New York 1990).

6. Edward Berkowitz, Disabled policy: America's programs for the handicapped (New York 1987).

7. Edward Berkowitz, Mr. Social Security: The life of Wilbur J. Cohen (Lawrence, Kansas 1995).

8. Jonathan Hughes, American Economic History (Glenview, Illinois 1987) 391.

9. William Leuchtenberg, FDR and the New Deal (New York 1963).

10. Arthur J. Altmeyer, The formative years of social security (Madison 1966) 13-15.

11. Wilbur J. Cohen, 'The Social Security Act of 1935: Reflections Fifty Years Later' in: Alan Pifer and Forrest Chisman (ed.), 50th Anniversary edition. The report of the Committee on Economic Security of 1935 (Washington, D.C. 1985) 12.

12. U.S. Commission on Civil Rights, Accommodating the Spectrum of Individual Abilities, Clearinghouse Publication 81, September 1983, p. 64, citing Mills v. Board of Education of D.C., 348 F Supp 866 (D.D.C.).

13. U.S. Commission on Civil Rights, Accommodating the Spectrum of Individual Abilities, citing Wyatt v. Stickney, 325 F. Supp. 381 (M.D. Ala. 1971); David J. Rothman and Sheila M. Rothman, The Willowbrook Wars (New York 1984).

14. See Edward Berkowitz, 'The ADA and the Social Security Act', forthcoming in a book on the Americans with Disabilities Act prepared by the Milbank Memorial Fund.

15. Don D. Lescohier, History of labour in the United States, 1896-1932. Volume III. Working Conditions (New York 1935); Edison L. Bowers, Is it safe to work? A study of industrial accidents (Boston and New York 1930).

16. Stuart Brandes, American welfare capitalism (Chicago 1976) 83, 103-107. 